\title{
Management Information System as a Technique in the Administration of Secondary Schools in ABA Zone South East Nigeria
}

\author{
Nwangwu Jane Uchenna Ph.D \\ Department of Educational Management \\ University of Port Harcourt, Nigeria \\ $+2347038188102$ \\ Uchennanwangwujane@yahoo.com \\ Ememe Ogbonna Nwuju Ph.D \\ Department of Educational Management \\ University of Port Harcourt, Nigeria \\ $+2348162094673$ \\ ememeon@yahoo.co.uk \\ Obike Comfort N. Ph.D \\ Department of Educational Foundations \\ University of Nigeria, \\ Nsukka \\ $+2348036706163$ \\ mummyobike@gmail.com
}

\author{
Accepted: June 15, 2013 Published: July 9, 2013 \\ Doi:10.5296/ijld.v3i3.4029 URL: http://dx.doi.org/10.5296/ijld.v3i3.4029
}

\begin{abstract}
This paper investigated management information system as a tool in the administration of secondary schools in Aba Education Zone, South East Nigeria. It was a descriptive survey to determine the extent secondary school administrator used MIS as a tool in administration. A sample of 44 principals and 210 teachers representing 44 and 10 percent of principals and teachers was selected from 100 principles and 2,100 teachers was selected through stratified random sampling representation. A 2-part, 15 item, 4-point Likert scale instrument was used to collect data for answering 2 research questions and for testing 2 null hypotheses at 0.05 level of probability. The instrument was validated by a team of experts in the department of Educational Management, Uniport, Nigeria, and a reliability value of $\mathrm{r}=0.85$ established. Mean was used to answer the research questions. T-test was applied to test the 2 null hypotheses. Findings show that result oriented administration and speedy execution of tasks constitute the general administrative performance of secondary school principals. It was concluded that proper implementation of and application of Management Information System will be profitable to the administrator, teacher, student and society at large. I recommended among others that government, Ministry of Education and the Secondary Education Board should equip schools with retrieval, dissemination and storage information system.
\end{abstract}




\section{Background to the Study}

The administration of secondary school has a broad complex function. This complex function emanated from the fact that the school system activities generate a wide range of records and reports, which has to be kept. Well processed and appropriately utilized to facilitate the process of effective school administration./ such records include accounting, auditing, budgeting, credit and collection, school enrolment records, staff record and a whole lot of other records and statistics that grow out of the operational activities of the school system, including the forces that influence human behaviour in the school organization.

Poor performance of administrators in Nigerian school system is an age-long issue. These problems could emanate from inability of the administrator to inquire, inform, persuade or entertain, problems resulting from poor administrative capacity for information management. Incompetence by adminis trators can lead to accumulated delay, poor quality and productivity, resources mismanagement and difficulties in decision-making.

Innovation in science and technology and the growing complexities in the world today demands administrators who can with the aid of modernized management information system handle information management process properly in the schools to meet their information needs.

In more recent times, the performance of the school system has come under heavy criticism. It is said that the students are not learning anything and this could account for the growing level of ind iscipline and examination malpractices among secondary school students. Others talk of the performance of the school administrators in terms of having adequate control of the teachers and other school system personnel. Sometimes, these school administrators are accused of not knowing what to do or not having the right and adequate information and at the right time to enhance their adminis trative process.

Management Information System is designed to assist managers in performing their work through an organized and most effective mode of information collection, processing, storage and retrieval model. Modern management information system is a network of computer-based processing procedures that are integrated with manual and other processes to provide timely, effective and efficient information to support managerial planning and control.

As part of the effective administration process, a good educational administrator organizes, plans, project, forecast, determines standards for and controls the educational institution or system for which he provides timely reports to the controlling management boards and ministries. Functionally, the administration of secondary schools tod ay require adminis trators that can carry out a structural set of operations in form of objective definition, by policies, designs and development of functions and definition of appropriate operation and tasks to achieve those objectives through the functions, definition and forecasting. Such structured tasks can only be effectively carried out if the management process is adequately supported by a system of organized information processing, storage and retrieval information system.

For an effective management information system to produce information that is accurate, timely and complete, yet concise, it must be supported by a manager that is skillful in information management as well as the necessary funds that make the information management system effective. For Management Information system to be an effective technique in the administration of secondary schools, it requires enough financial and material resources. Management Information System (MIS) is the most common form of management 
support system. It provides managerial end-users with information products that support much of their day-to-day decision making needs. Management information system (MIS) provides a variety of report and displays to management to enhance their decision making and communication process. Management information system retrieves information about internal operations from databases that have been updated by transaction processing system. It also provides data about the school environment from external sources and also stores information about the present situation of the school.

Information products provide to administrators includes displays and report that can be furnished (1) on demand (2) Periodically, according to a predetermined schedule or (3) whenever exceptional condition occur. Activities that occur in any information system include recognized input, processing output, storage and control activities. There are other information techniques available to the administrators. Dickson (1968) identified the various techniques available for information management and decision making. Such techniques include the Decision Support System (DSS), the Executive information system (EIS), the Operation Support System (OSS) and the Network Management Information System (NMIS). The application of any of these produces what is generally recognized as organized Management Information System.

Foundation of Information System (2000) recognizes that Decisions Support System is a natural progression from management information and transaction. Decision Support System (DSS) are intensive computer-based information system that use decision models and specialized database to assist the decision-making processes of managerial end users. DSS is a set of computer programmes and hardware that help managers arrange information from various sources in new and different ways. It supports all forms of information requirement for decision making.

Executive Information System (EIS) are other types of information management techniques. They are management support systems tailored to the strategic information needs of top and middle level management end users. Such support systems are designed to give the top management an easy way to get the critical information they want in other of their preferences for speedy decisions.

The third technique is the Operations Support System (OSS). It processes data generated by transactions in course of operational activities. It produces variety of information products for internal and external use. The role of a business firm's operation support system is to efficiently process business transaction, control industrial process, support office communications operations and management classification of information.

In the light of these, management information system (MIS) grew out of simple data processing systems. It was a step in information summarizing to help managers make decisions. Management information systems provide information in the form of pre-specified reports and display to managers. It coordinates the resources needed to convert data (inputs) into needed information (outputs) in order to achieve the objectives of an organization. It is concerned with past actions and outcomes and ends result. The management in performing its duties involves organized set of people's procedures, designed equipment (usually computers) and supplies the right information to the management needed for better planning control and decision making. 
The administration of secondary school is increasingly becoming complex. The application of modernized information management techniques to enhance effective and speedy decision- making can therefore not be ignored.

\section{Statement of the Proble m}

With regard to the administration of secondary schools in Abia State, not much is known about these allegations. Are the school administrators actually performing below expectations in terms of their adminis trative assignment? Are they managing their information well to enhance modern decision-making in their administrative process? Do they have the capacity for computer-based management information system? Are they in fact adopting modernized management information system in their day-to-day administration of their schools? If not, what could be inhibiting them at this period of technological innovations? These are the issues that bother the researcher in this study.

\section{Purpose of the study}

The purpose of this study is exemplified by the following objectives:

1. To ascertain if school administrators adopt modernized management information system and which particular one they adopt.

2. To ascertain whether school administrators have adequate capacity for modernized management information system.

\section{Hypotheses}

1. There is no significant difference between the opinion of principals and teachers on the level of adminis trative performance of secondary school administrator in Abia State.

2. There is no significant difference between the opinion of principals and teachers on the school administrators' capacity for modernized management information system.

\section{Methodology}

This was a descriptive survey. The study involved an assessment and description of the phenomenon of information system application in the school system. It was aimed at determining the extent to which secondary schools administrators used management information system as a veritable tool in administration. All the 100 principles and 2, 100 teachers in Aba Zone, Abia State Nigeria made up the population. A sample of 44 principles, 210 teachers representing $44 \%$ and $10 \%$ of principals and teachers in Aba zone was selected through stratified random sampling representation.

A 2-part, 21-item, 4-point scale instrument known as School System Information Management Questionnaire (SSIMQ) was used to generate data for answering 2 research questions and for testing 2 null hypotheses at 0.05 level of probability. The instrument was validated by a team of experts in the department of Educational Management, University of Port-Harcourt, Nigeria and a reliability value of $r=.85$ established through test-retest method that generated data that were subjected to Pearson's Product Moment Correlation. The researcher personally went round to administer the questionnaire to tee teachers and principles sampled for the study. Mean was used to answer the research questions. T-test statistics was applied to test the 2 null hypotheses on significance difference. 


\section{Results}

Research Question 1: What is the general administrative performance of secondary school principals?

Table 1: Mean and Standard Deviation of principals and Teachers' Assessment of administrative performance of principals

\begin{tabular}{|l|l|c|c|c|c|}
\hline \multirow{2}{*}{ S/n } & Administrative Performance Variables & \multicolumn{2}{c|}{ Principals } & \multicolumn{2}{c|}{ Teachers } \\
\cline { 3 - 6 } & Mean & SD & Mean & SD \\
\hline 1. & Result oriented Administration & 3.27 & .66 & 3.11 & .71 \\
\hline 2. & Speedy execution of tasks & 2.72 & .85 & 2.70 & .80 \\
\hline 3. & Functional links with school Board & 2.84 & .71 & 3.23 & .66 \\
\hline 4. & Effective ins tructional supervision & 2.50 & .80 & 2.90 & .72 \\
\hline 5. & Healthy staff relations & 2.80 & .93 & 3.10 & .75 \\
\hline 6. & High level of discipline & 2.60 & .90 & 2.84 & .80 \\
\hline 7. & Staff commitment to duty & 2.80 & .90 & 2.94 & .74 \\
\hline 8. & Healthy school-community relations & 2.70 & .55 & 2.90 & .82 \\
\hline & Aggregate Mean & $\mathbf{2 . 7 7}$ & $\mathbf{. 3 9}$ & $\mathbf{2 . 9 5}$ & $\mathbf{. 4 7}$ \\
\hline
\end{tabular}

In the above data analysis, it shows that principals and teachers were of the opinion that the school principals are moderately focused on achievement of results (3.27 for principals and 3.11 for teachers); achieve functional links between the school and the ministry (2.84) for principals and 3.23 for teachers); maintain healthy staff relations (2.80 for principals and 3.10 for teachers); and ensures that staff are committed to duty (2.80 for principals and 2.94 for teachers). They equally achieve moderate performance in the area of speed y execution of tasks, healthy school-community relations, discipline and effective instructional supervision. This is because as shown in the table, all the mean is up to and above 2.50 , which is the dividing line between negative and positive condition favorableness. Adding up the respective mean weights and dividing the sumby the number of items, gave an aggregate mean weight of 2.77 for principals and 2.95 for teachers respectively. This clearly shows that whether by the opinion of principals or teachers, secondary school principals are exhibiting moderate performance in school administration.

Research Question 2: What is the capacity of the school administrators for modernized information management?

Table 2: Mean and Standard Deviation of Principals and Teachers' Opinion on the Modernized Information Management Capacity of School administration.

\begin{tabular}{|l|l|c|c|c|c|}
\hline \multirow{2}{*}{ S/n } & \multicolumn{2}{|c|}{ Pdincipals } & \multicolumn{2}{c|}{ Teachers } \\
\cline { 3 - 6 } & Availability of Computer system & 1.93 & 1.10 & 1.77 & 1.01 \\
\hline 2. & Information Processing to aid decision & 2.70 & 1.05 & 2.71 & 1.02 \\
\hline 3. & $\begin{array}{l}\text { Information processing knowledge by school } \\
\text { principals and that in-charge of information } \\
\text { processing. }\end{array}$ & 1.68 & 1.03 & 1.68 & 1.00 \\
\hline 4. & $\begin{array}{l}\text { Personal training in modern information } \\
\text { management skills }\end{array}$ & 1.48 & .73 & 1.62 & .90 \\
\hline 5. & $\begin{array}{l}\text { Knowledge of computer and information } \\
\text { processing system by staff }\end{array}$ & 1.50 & .63 & 1.78 & .80 \\
\hline 6. & Availability of regular power supply & 2.11 & .93 & 1.86 & .99 \\
\hline 7. & $\begin{array}{l}\text { Receptive attitude of staff to computerization } \\
\text { and MMIS }\end{array}$ & 2.77 & .94 & 2.83 & \\
\hline & Aggregate Mean & $\mathbf{2 . 0 3}$ & $\mathbf{. 4 6}$ & $\mathbf{2 . 0 4}$ & $\mathbf{. 5 2}$ \\
\hline
\end{tabular}


Going by the principal's opinion of both school principals and teachers, school administrators have very poor capacity for MMIS. It is only in the areas of processing information for decision making and attitude to modernized management information system that they have moderate capacity. This is revealed by the weighted mean scores of these variables falling below 2.50 for all the variables except these last two mentioned (see the respective mean score in table 2). The summary as revealed by the aggre gate mean clearly shows very poor capacity for MMIS, since their mean fall below 2.50 .

\section{Hypotheses}

Hypothesis 1: There is no significant difference between the opinion of principals and teachers on the level of administrative performance of secondary school administrator in Abia State.

Table 3: Mean SD and t-test of Difference between the opinion of principals and researcher on the level of administrative performance of school administration.

\begin{tabular}{|l|l|c|c|c|c|c|c|}
\hline S/N & Variable Category & N & Mean & SD & T-value & 2 Tailed Sig. & Remarks \\
\hline 1. & Principals & 44 & 2.77 & .39 & -2.433 & .018 & Significant \\
\hline 2. & Teachers & 210 & 2.95 & .47 & & & \\
\hline \multicolumn{7}{|c|}{ P > .05 }
\end{tabular}

The result of the analysis in Table 6 revealed a mean of 2.17 for principals and 2.95 for teachers. The difference between these two mean shows a calculated t-value of -2.433 , which is significant at .018. Since this a significant point of the calculated $t$-value is less than .05 , the point at which the hypothesis is being tested, the researcher considers the difference to be significant and therefore rejected the null hypothesis.

Hypothesis 2: There is no significant difference between the opinion of principals and teachers on the level of administrative performance of secondary school administrator in Abia State.

Table 4: $\quad$ Mean, SD and t-test of differences between the opinion of principals and teachers on the capacity of the administration for MMIS

\begin{tabular}{|l|l|c|c|c|c|c|c|}
\hline S/N & Variable Category & N & Mean & SD & T-value & 2 Tailed Sig. & Remarks \\
\hline 1. & Principals & 44 & 2.33 & .76 & -.392 & .695 & Not Significant \\
\cline { 1 - 5 } 2. & Teachers & 210 & 2.38 & .68 & & & \\
\hline
\end{tabular}

The researcher also carried out t-test analysis to see if the assessment of the school administrators' capacity for implementation of MMIS differs between the principals and the teachers. The result is shown in table 4. This test as reflected in Table 4 shows that there is no significant difference. Null hypothesis is therefore not rejected this means that both the principal and the teachers hold the same opinion.

\section{Summary of Findings}

1. General administrative performance of secondary school principals include:

a. Result oriented adminis tration, speedy execution of tasks, functional links with school board, effective instructional supervision, healthy staff relation and high level of discipline.

2. The capacities of school administrators fort modernized information management include: 
a. Information processing to aid decision and receptive attitude of staff to computerization and MMIS.

3. The hypothesis which states that there is no significant difference between the opinion of principals and teachers on the level of administrative performance of secondary school administrators in Abia State is hereby rejected.

4. The hypothesis which states that there is no significant difference between the opinion of principals and teachers on the school administrators capacity for modernized management information system is hereby accepted

\section{Discussion of Results}

Findings reveal that management information system leads to a result oriented administration and speedy execution of tasks. These are in agreement with UNESCO (1979) who maintained that information gives the possessor power and influence over and above the authority he may be legally vested with. Additionally, according to UNESCO is the fact that that the first principle in achieving managerial effectiveness is to have access to the most reliable and up-to-date information.

Lending his voice in support of the above Hindorf (2002) contended that information management is not an end in itself, but is designed to assist administrators carry out their mandate more effectively. In this context therefore, Hillderband (1999) stated that information needed by administrators depends on the scope of their administrative tasks and the specific purpose to be served by such information.

In corroboration with the above, Fields (1994) emphasized that modernized mana gement information system, produced rapidly in the implementation of administration of programmes can provides the best framework for project monitoring.

In keeping with the above findings, Gottschalk and Hogskolen (2004) noted that information management system must therefore be tailored to meet the requirement of management if it is to serve the purpose it is meant to.

Similarly, Thorn (2001) recognized that the burden of information management that is placed on educational system leaders is enormous and increasing by the day. This is because of changes in technology, societal values, needs for accountability, rise in drop-out rate, ethnic diversity, gender imbalance in educational participation, disparity in educational outcome among groups and the rest. This authority believes that it only modernized information management system that can adequately handle such enormous information processing requirement of modern school system.

Results indicate that information processing aids decision-making and that staff have receptive attitude to computerization and management information system. This is in harmony with the work of Mahotra (2003) in an empirical study that revealed that those who adopt modern information management technique show better performance in comparison with their counterparts. In confirmation with the above, Maduagwu (1998) opined that the importance of MIS cannot be over-emphasized because of its vital benefits of reducing cost, time and improving the quality and quantity of information flow. This author added that MIS can be used to plan for expansion of a new school based on the population growth rate in the area and the economic activities of the people. 


\section{Conclusion}

The study showed that proper implementation, adaptation and application of MMIS will be profitable, to administrator, teacher, student and society at large. In other words, to determine the profitability of MMIS in secondary Education, the quantifiable and non-quantifiable or complex and immeasurable factors, constitute the criterion for investment in secondary school.

\section{Recommendations}

Based on the findings of the study, the following recommendations were made:

a. The Secondary Education Management Board should urgently embark on the provision and the equipment of secondary schools with the most current MMIS for profitability to adminis trators, students, teachers and the society at large.

b. A seminar to educate or enlighten our administrators should be organized to enable them be computer literate for effective and efficient manipulation of MMIS to create easy and self retrieval, dissemination and storage of information.

\section{References}

Fields, D. L. (1994). Training manuals for the computerized acquisition and resettlement management system (ARMS) for Resettlement and Rehabilitation Operations. Washington, D.C: World Bank.

Gohschalk, P, Hogskolen, D. P. (2004). Strategic Information System Planning: The implementation on Challenge. Barriers to the implementation of strategic information system plans: a Literature Review posted on the web. http:/hsb.baylor.edu/ramsowers/ais. Ae.97/papers

Hilderbrand, C. (1999). Does KM = IT? CIO Enterprise, Sept 15, URL:http:www.cio.com/archive/enterprise/091599

Hindoff, D. (2002). "GE"s drive to real-time measurement" CIO insight, No. 11, http://www.uoinsight.com Last Examined, Nov 18, 2002

Maduagwu, S. N. (1998) Educational Management in Nigeria Concepts. Presbasy Printers \& Publishers: Port Harcourt, Rivers State

Malhortra, Y. (2003). The knowledge application gap in information systems research and education and their quest for the dependent variable. Information Resource Management Journal, Vol. 16 (2) April, Pp i - vi

Thorn, C. A. (2001). Knowledge management for educational information system: What of the state of the field: Educational Policy Analysis Achieves 9 (47). Retrieved August, 2004 from http://epaa.asu.edu/epaa/vgn47 
UNESCO (1979). The computerized Management of Educational System / Accompanying documents. Paris: UNESCO Headquarters 